\title{
WORLD FEDERATION OF SOCIETIES OF ANESTHESIOLOGISTS AND WORLD CONGRESS OF ANESTHESIOLOGISTS
}

Plans are progressing favourably for a great international gathering of anaesthesiologists to be held at Scheveningen, near The Hague, Holland, September 5-10, 1955. The Netherlands Society of Anesthesiologists will be our hos̀ts, and they are preparing a scientific programme for the Congress. Societies of anaesthesiologists in twrenty-five countries have signified their intention to becorme members of the new World Federation which has been under consideration by an Organizing Committee for the past four years. The World Congress of Anesthesiologists and the inaugural Assembly of the World Federation are under the high patronage of Her Majesty The Queen of the Netherlands, who has graciously consented to open the proceedings in a formal ceremony to be held at the Parliament Buildings in The Hague.

The Congress will be devoted to discussion of scientific subjects and a large number of papers will be presented by anaesthesiologists from many countries. The official languages of the Congress are English, French, and German, and translation into English will be avalable at all tımes. The principal subjects which will comprise the programme of the Congress are.

(a) Muscle Relaxation;

(b) Hypotension;

(c) Hyperthermia and Artuficial Hibernation,

(d) Respiration and Circulation;

(e) The Teaching of Anaesthesia.

All inquiries and communications regarding the scientific programme, registration, hotel accommodation, etc. should be addressed to Mr. W. A. Fentener van Vlissingen, Executive Manager, World Congress of Anesthesiologists, BILTHOvEN, Holland. The Chairman of the Organizin 3 . Conmittee for the Netherlonds is Dr. C. R. Ritsema van Eck, Groningen, the Secretary, Dr. M. Mauve, Heemstede; and the Treasurer, Dr. L. A. Boeré, Leiden Lady B. M. de Beaufort is un charge of the ladies' entertainment and the social aspects of the programme, whic a will,include trips through interesting old towns, showing canals, windmills, flower sales, etc. Registration fee for the Congress will be 35 Dutch guilders (approximately $\$ 8.00$ Canadian) for active members, and 10 guilders for lady guests.

Last June, I attended a meeting of the Organizing Committee for the World Federation of Societies of Anestlesiologists which was held at Scheveningen, and I had an opportunity to visit the hotels and the meeting-halls which will accommodate the World Congress. There are three resort hotels adjacent to the meeting-hall on a beautiful beach facing the North Sea. Accommodation and service are excellent, and the meals very good indeed-in fact I was very favourably impressed by the whole attitude of our Dutch colleagues and by the excellence of the pre sarations which they are making for the Congress. The name of Canada is oved and respected in Holland, and I am sure that every Canadian anaesthetıst who attends the Congress will have a wonderful time. 
The World Federation, which will come into being at the same time as the Congress, wll be a contunung body which we hope will bind together anaesthe tists in all countries in order to provide better anaesthesia for all the peoples of the world. The Federation will act as a clearing house for information regard urg standards of anaesthesia training, available residencies, and other matters of common interest. It will help the organization of societies of anaesthesiologists in countries where the specialty is just beginning, and it will hold periodic World Congresses at intervals of perhaps three or four years. The most important officer of the new Federation will be the Sécretary-Treasurer, to be elected by the first General Assembly. The Association of Anaesthetists of Great Britain and Ireland have named Dr. Geoffrey Organe of London for this post, and the members of the Organizing Committee hope that the delegates to the General Assembly will accept this very suitable nomination. The _eadquarters of the Federation will then be set up, in a modest way, in London.

According to the proposed Constitution of the World Federation, the Canadian Anaesthetists' Socrety will be entitled to three official delegates to the General Assembly.

The General Assembly will elect an Executive Committee which will carry on all the activities of the Federation in the interval between General Assembly meetıngs.

I ho se that Canada may be well represented in both the Fedleration and at the World Congress.

Montreal, January 13, 1955

Harold R. GRIFFIth, M D

\section{WORLD FEDERATION OF SOCIETIES OF ANESTHESIOLOGISTS}

(Draft Constitution, as revised June, 1954)

\section{SeCtion I. Name and Headquarters}

Art. I-In conformity with the decisions of its first General Assembly of 1955, an international non profit making scientric Society to be known as the WORLD FEDERATION OF SOCIETIES OF ANESTHESIOLOGISTS is hereby set up

Art. 2-The statutes of the Federation shall be registered in. . . .

\section{SECTION II. Purposes and Functions}

Art. 3-The ob ect of the Federation is to make avallable the highest standards of anesthesia to al peoples throughout the world.

In pursut of this aim, the functions of the Federation shall in particular include the following:

(a) To assist and encourage the formation of national Societies of anesthesiologists.

(b) To promote the dissemination of scientfic information.

(c) To recommend desirable standards of training for anesthesiologists:

(d) To provide information regardıng opportunities for postgraduate training and research.

(e) To encóurage research into all as jects of anesthesiology.

( $f$ ) To encourage the establishmerit of safety measures including the standardization of equirment.

(g) To adv se upon request national and international orgamizations. 


\section{SECTron III. Membership}

Art. 4-The members of the Federation shall be the national Societies known to and certified by the Interim Committee for the establishment of this Federation including, the National Societies of Argentine, Austria, Australia, Belgium, Brazll, Canada, Chle, Colombia, Cuba, Denmark, Finland, France, Germany, Great Britain \& Ireland, Israel, Italy, Netherlands, New Zealand, Norway, Philippines, South Africa, Sweden, Switzer land, Spain, United States of Amenca, Uruguay, together with such organizations as shall be approved by a vote of a majority of the aforesaid members present at the first General Assembly of the Federation which shall be held without notice immediately following the adoption of these articles.

Art. 5-Membership of the Federation shall be granted to other natıonal organizations approved by the General Assembly in accordance with these articles and following the procedure cetermined in the by-laws.

Art. 6-Only one organization per country shall be permitted to membership of the Federation.

Art. 7-In addition to member organizations there shall be "Associates of the Federaation" consısting of anesthesıologists holding a registered medical qualification from countries where there is no recognized organization of anesthesiologists. Associates will be admitted by the Executive Committee after application and shall have such rights, privileges and duties and shall pay such annual subscription as the Executive Committee may determine. The Executive Committee shall have the right at any time to suspend the membership of an Associate of the Federation who shal have the right of appeal to the next General Assembly. The General Assembly may by a two-thirds majority expel such Associate member.

Art. 8-A member organization or an "Associate member" may resign at any tume followng the procedure determined in the by-laws Membership of a member organization may be terminated by a vote of the General Assembly by a two-thirds majority in the following cases.

(a) If a change in the nature of the activities of the member organization makes it inappropriate for continued membershrэ.

(b) if the member organization wilfully de aults in the payment of its subscription.

Art 9-Organizations which for any reason cease to be members of the Federation shall have no rights in the Federation's funds and shall not be entitled to demand a statement of account, to affix the seals to the Federation's property nor to demand an inventory.

\section{Section IV. General Assembly}

Art. 10-The Federation shall be governed by a General Assembly of delegates from member organizations. Each member organization shall be entitled to one delegate if the number of its members is 250 or fewer. It will be entitled to 2 delegates if it numbers from 251 to 500 members, to 3 if it numbers from 501 to 1,000 members, and to one extra delegate per 1,000 members over 1,000. The delegates must be qualified anesthesiologists.

Any national member organization which desires to ensure its full quota of representatives at meetings of the General Assembly by the appointment of alternates for its règularly named delegates may do so, provided that no such alternate shall be permitted to participate in the work of the General Assembly until he has been duly certified to the Secretary-Treasurer of the Federation as assuming the powers and duties of the delegate he has been designated to replace.

No person shall be a member of the delegation of more than one country.

Art 11-Voting by the General Assembly shall be by individual delegates. 
Art 12-Each member organization shall be required to forward to the SecretaryTreasurer the name(s) of its accredited representative(s) before the opening of the session of the General Assembly.

Art 13-The General Assernbly shall meet in ordinary session on the occasion of each international congress. It shall meet in extraordinary session as circumstances may rec uire.

Extraordinary meetings of the General Assembly shall be convened by the Executive Committee, either on its own responsibility or at the request of not less than two-thirds of the member organizations.

Art 14-The General Assembly shall be the supreme body of the Council and shall be entitled to take cognizance of all matters not exslicitly precluded by these articles.

The principal functions of the Assembly shal be

(a) to determine the policy of the Federation;

(b) to elect the Executive Committee and the Secretary-Treasurer in accordance with these articles;

(c) to receive and approve the reports of the Executive Committee;

(d) to fix the scale of subscriptions, to supervise the financial policy of the Federation and to scrutinize and approve the budget and accounts.

Art 15-The Executive Conmittee shall prepare the agenda of the Assembly and shall forward the same to full members simultaneously with the notice of the Assembly.

Art 16-The General Assembly shall elect a president at the beginning of each session with three vice-presidents or more at its discretion.

The Assembly shall deal with the items on the Agenda and such other matters as it may decide to add thereto.

The Assembly shall adopt its rule of procedure.

Art. 17-Decision shall be by simple majority of the members present and voting, affirmative or negative votes alone being valid, nevertheless a majority of two-thirds shall be necessary for the admission or expulsion of members or for the amendment of these statutes.

The Assembly shall only be entrtled to debate such amendments if they have been included in the agenda attached to the notice of the meeting, or if not less than twothurds of the full members are present or represented.

If a vote is equally divided, the president shall have a casting vote.

Art. 18-Decisions of the General Assembly shall be recorded in minutes signed by the oresident and the executive secrettary and by such members as desire to do so. The Minutes shall be kept at the headquarters of the Federation and shall be open for perusal by all interested parties. Copies or extracts from the minutes shall be signed by the charman of the Executive Committee and the Secretary-Treasurer.

One free copy of al minutes shall be forwarded by the Executive Committee or the Secretariat to each ful member.

\section{Section V. Executive Committee}

Art 19-The Executive Committee shall execute the decisions of the General Assembly and take within the limits of those decisions all measures designed to further the purposes of the Federation.

The Executive Committee shall consist of 12 members of whom at least one must be from (a) Europe, $(b)$ tie U.S.A. and Canada, $(c)$ Latm America, (d) Asia and Australasia, and one mem ser from each of the two largest member organizations.

The Executive Committee shall have power to co-opt to three additional members who shall serve until the next period of reelection. 
Half the members (other than the Secretary-Treasurer) of the Executive Committee shall retire at each rejular meeting of the General Assenably and shall not be eligible for immediate reelect.on.

Outgoing members in the first instance shall be selected by lot, and subsequently by rotation.

Where vacancies arise from retirement or other: causes, the Executive Committee itself shall fill such vacancy or vacancies provisionally.

Persons elected to the vacancies aforesaid shall serve for the remainder of the term of the member they replace. Where requisite, the next General Assembly shall proceed to a regular election.

Art. 20-The Chairman and his deputies will be appointed by the Executive Committee from among its members.

The Secretary-Treasurer, who will have right to vote, shall be elected by the General Assembly.

The Executive Committee shall nommate the Secretary-Treasurer three months in advance of the Gerieral Assembly.

Counter nominations may be made by three votmg, menzbers of the General Assembly, nominations to be received at least two months be_ore the General Assembly.

The Secretary-Treasurer shall hold office until the termmation of each regular meeting of the General Assembly and shall be avarlable for immediate reelection.

Art. 21-The Executive Committee shall meet before and during each session of the General Assembly and whenever the interests of the Federation so requires on the summons of its chairman or his deputy.

Art. 22-Voting in the Executive Committee shall conform to the rules laid down in these articles for votıng in the General Assémbly.

The Secretary-Treasurer may request the Executrve Committee to take decisions by postal ballot.

Art 23-The Secretary-Treasurer shall forward to each rnember organization an annual report of the Federation.

\section{Section VI. Finance}

Art. 24-The resources of the Federation will originate rom.

(a) Annual contribution pard by member organizations, the scale of which shall be fixed by the General Assembly and shall be related to the number of votes of each member association:

(b) Annual subscription of the associates of the Federation:

(c) Subsidies, gifts and bequests that might be bestowed, on the Federation and accepted by the Executive Committee.

(d) Profits accruing from international congresses.

Art. 25-The Secretary-Treasturer shall make up the accounts and budgets of the Federation as at 31 December yearly and prepare the same for inspection by 31 March following at the latest. The audited accounts shall be forwarded to member organizations together with the yearly report.

\section{Section VII. Dissolution and Liquidation}

Art. 26-In the event of the dissolution of the Federation for any reason or at any time, lic uidation shall be carned out by the person appointed by the Genneral Assembly, wizich shall decide upon his powers and, if relevant, his emoluments.

Falling the appointment of a liquidator, liquidation shall be carried out by the Executive Committee then in office acting as a Panel of Liquidators. Such Panel shall have powers without restrictions or limitations. 


\section{SECTION VIII. Entry into Force}

Art. 27-These statutes shall become effective when ten of the organizations particlpating in the first General Assembly shall have accepted them.

The several governing or administrative organs of the Federation shall then take up their full duties in accordance with the directives received.

Art. 28-The English text of the statutes and by-laws shall be considered as authoritative. 